\title{
Groundwater Quality Evaluation in Mando and Rigasa Areas, Kaduna, Northwestern Nigeria
}

\author{
Alimi J. Aª Idris-Nda, $A^{\mathrm{a}}$., Ajayi, $\mathrm{O}^{\mathrm{b}}$. and Konwea, C. I ${ }^{\mathrm{b}}{ }^{*}$ \\ aDepartment of Geology, Federal University of Technology, Minna \\ bDepartment of Geology, Obafemi Awolowo University, Ile-Ife \\ *Correspondence: iykekonwea@yahoo.com
}

\section{DOI: 10.2478/pjg-2021-0003}

\begin{abstract}
:
The quality of groundwater from twenty (20) hand-dug wells around the Mando and Rigasa areas, Northwestern Nigeria was evaluated in this study. Physico-chemical parameters like pH, EC, TDS, temperature, $\mathrm{Na}^{+}, \mathrm{Ca}^{2+}, \mathrm{K}^{+}, \mathrm{Mg}^{2+}, \mathrm{Fe}^{2+}, \mathrm{Cl}, \mathrm{HCO}_{3}{ }^{-}, \mathrm{NO}_{3}{ }^{-}, \mathrm{SO}_{4}{ }^{2-}$ and faecal coliform count were analysed. The degree of compliance of the various parameters with international guidelines for drinking water quality were determined and the groundwater classified. Comparison of the results of physico-chemical analysis with the NSDWQ and WHO guidelines revealed that most of the parameters in the groundwater had $100 \%$ compliance except for $\mathrm{pH}, \mathrm{Mg}^{2+}, \mathrm{NO}_{3} ; \mathrm{K}^{+}$and $\mathrm{Fe}^{2+}$ with percentage compliance of 80, 90, 75, 70 and 40, respectively. This indicates that some of the groundwater samples are not suitable for drinking purpose. Groundwater quality map based on the Water Quality Index values for the various groundwater sample showed that most parts of the study area have excellent groundwater quality. The faecal coliform bacteria count ranged from $0 \mathrm{CFU} / 100 \mathrm{ml}$ to too numerous to count. Only two (2) groundwater samples (10\%) complied with the $0 \mathrm{CFU} / 100 \mathrm{ml}$ guidelines of the NSDWQ and WHO, while the rest eighteen (18) groundwater samples ( $90 \%$ ) have faecal coliform bacteria count above the recommended value. Most of the groundwater samples are not suitable for drinking based on the faecal coliform count. The groundwater samples are suitable for agricultural purposes based on the SAR, RSC and PI classifications. The groundwater in the study area is dominated by $\mathrm{Na}-\mathrm{Cl}$ and $\mathrm{CaHCO}_{3}$ - type facies water.
\end{abstract}

Keywords: water quality, water classification, groundwater origin, Kaduna, Northern Nigeria

\subsection{Introduction:}

Much effort has been made by governments, organisations and individuals to explore and develop groundwater systems for domestic, agricultural and industrial uses due to the attendant shortcomings of the surface water. Surface water resources most often are short in supply, degraded in quality or not readily available on site; hence, their development in most cases becomes extremely capital intensive. In the groundwater development interventions by various agencies, very little efforts have been put to groundwater quality in terms of protection and management. The emphasis at present is not only to detect and develop new groundwater systems to meet up with the targeted goal, but also to protect those sources [1]. The successful implementation of the Millennium Development Goals (2000-2015) helped to foster greater efforts towards improving access to drinking water supply and sanitation [2]. The United Nations Organisation (UNO) recommended five target areas for Sustainable Development Goals (SDGs 2016-2030) for water to comprise (i) Water supply, Sanitation and Hygiene (WASH); (ii) water resources; (iii) water governance; (iv) water quality and wastewater management; and (v) waterrelated disasters [2]. These recommendations cover four (4) key areas, which are exploration, exploitation, protection and management of water sources. The failure of one or more of these key areas could lead to the failure or compromise of the water supply source.

Water means life only when it is wholesome and free of contaminants. About $30 \%$ of the freshwater on earth is found as groundwater in geologic formations called aquifers [3]. An aquifer is defined as a geological formation (or sometimes part of a formation or a group of formations) that contains saturated material of sufficient permeability to yield economic quantities of groundwater to wells and/or springs [4]. Water seeping down from the land surface adds to the groundwater in a process called groundwater recharge. Groundwater is recharged from rain water, snowmelt or water that leaks through the bottom of lakes and rivers. Groundwater can also be recharged when water supply systems (pipelines and canals) leak and when crops are irrigated with more water than the plants can use [5]. The water that flows on and through geological materials dissolves and carry substances with it. The concentration of the different chemical substances of interest in the water determines its quality. Water is a universal solvent, capable of dissolving and carrying components of the material it flows through. This is why the chemical composition of water is often used to trace the history and flow path of the water [6, 7]. The concentration of various constituents of water depending on the length of time water interacts with a given environment and the nature of the constituents. Water in the atmosphere is capable of dissolving and carrying gases such as nitrogen, carbon dioxide and sulphuric acid. Nitrogen, phosphorus and potassium from agricultural land are also dissolved and carried by water during surface runoff or groundwater recharge [8, 9]. Studies have shown that weathering activities affect groundwater composition [10]. When rock breakdown during weathering, the rock materials are dissolved and carried by groundwater flowing through the rock materials. These dissolved materials carried by groundwater affect water quality.

Under natural conditions, groundwater is usually potable and needs almost no treatment before use. The potablility of groundwater depends largely on the protective capacity of the soil and rocks in the unsaturated zone above the water table. Groundwater quality is influenced by the chemical composition of the aquifer through which it and the various land use activities such as urbanisation and industrialisation migrates [11]. Worldwide, aquifers, especially shallow aquifers, are susceptible or vulnerable to contamination from land use activities such as urbanisation, leaking tanks, oil spillage, landfills, sewage (latrines, septic tanks), intensive agriculture (fertilizers, herbicides and pesticides), mining activities and heavy metals, which are directly washed into groundwater systems [12-14]. Groundwater contamination, especially in shallow unconfined aquifers occurs both within the Basement Complex and sedimentary terrain of Nigeria $[15,16]$. The Mando and Rigasa areas on the outskirts of Kaduna metropolis (Fig. 1), Northwestern Nigeria are fast growing communities where there are no pipe-borne water and the rivers in the areas, though perennial, are polluted with domestic and agricultural wastes and are unfit for consumption [17]. The residence of Mando and Rigasa areas has resorted to the use of groundwater as an alternative source of water supply to meet their daily water needs.

Groundwater is less prone to contamination than surface water due to the protective covering provided by geologic materials. Although, the degree of protection of groundwater from surface contaminants depends on the nature of the geologic material providing the covering. Fine grained materials such as clay have low permeability due to the platy alignment of the individual grains. The platy alignment restricts the flow of water, causing contaminants and other dissolved matter to precipitate out of solution as the water flows through it. Coarse grained materials such as sand and gravel have high permeability, allowing for easy flow of water through its pores. The high permeability increases the chances of groundwater contamination in areas where sandy and 
gravelly materials provide covering for the groundwater. Therefore, domestic and agricultural wastes affect groundwater quality, especially in an environment where the topsoil is composed of coarse materials. Groundwater within sandy tropical environment of the Mando and Rigasa areas is exploited through hand-dug wells and shallow drilled boreholes. The rapidly increasing population of these areas and the unplanned and unregulated waste disposal and sewage system call for concern on the status of the groundwater in which the Mando and Rigasa residence rely on. The health of the people may be impaired by drinking unwholesome water. The consumption of unwholesome water has led to severe illnesses and death [18]. The situation in Mando and Rigasa areas of Kaduna State calls for an assessment of the groundwater quality of the areas to avoid water related illnesses and death. This study therefore aims to evaluate the groundwater abstracted from the shallow aquifers of the Mando and Rigasa areas to determine its hydrochemistry and suitability for drinking and agricultural purposes.

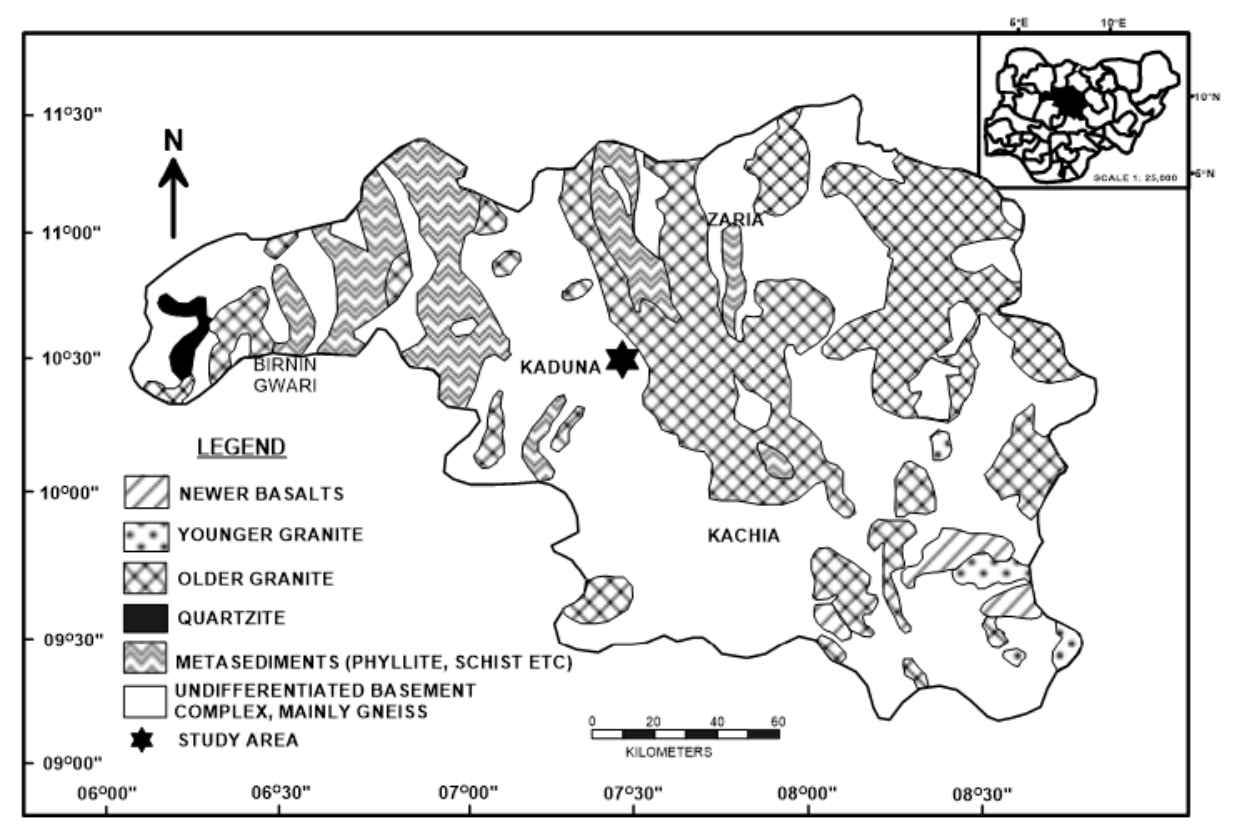

Figure 1. Generalised Geological Map of Kaduna State, Nigeria [19]

The objectives of this study are to:
i. Carry out inventory of hand-dug wells around the study area;
ii. Carry out groundwater sampling and chemical analysis;
iii. Assess the suitability of the groundwater for drinking and agricultural use; and
iv. Determine the origin and classification of the groundwater.

\subsection{Geological Setting}

The Mando and Rigasa areas lie within latitudes $10^{\circ} 32^{\prime} \mathrm{N}$ and 10 $36^{\prime} \mathrm{N}$ and longitudes $7^{\circ} 22^{\prime} \mathrm{E}$ and $7^{\circ} 26^{\prime} \mathrm{E}$ (Figure 2), in Igabi Local Government Area of Kaduna State. The areas fall within the southeastern part of Kaduna, Nigeria. The study area is within the tropical Savannah climate with distinct dry and wet seasons. The dry season occurs between October and April while the wet season is between May and September. These two seasons reflect the influences of tropical continental and equatorial maritime air masses that sweep over the entire country. The annual rainfall ranges between $793.4 \mathrm{~mm}$ and $1655.2 \mathrm{~mm}$ with a mean annual rainfall of $1197.1 \mathrm{~mm}$. The mean monthly rainfall ranges from $0 \mathrm{~mm}$ in the driest months to above $300 \mathrm{~mm}$ in August, while the diurnal temperature ranges between $9 \mathrm{oC}$ and $34 \mathrm{oC}$ [14]. The vegetation in the area is of typical guinea Savannah, characterised by sparse shrubs and interrupted by large isolated trees. There is more continuous grass cover in the rainy season than the dry season. The area is still undergoing urbanisation, subjecting most part to the construction of settlements, commercial and related infrastructure. The cultivation of cereals and vegetable is practised in the area. The landform in and around the area is gently undulating with heights above the mean sea level not more than $640 \mathrm{~m}(2100 \mathrm{ft}$.). The area is drained by River Mashi and its tributaries, which form a dendritic drainage pattern. This drainage network empties into the main River Kaduna in the eastern part of the study area. The study area is underlain by Basement Complex rocks of high-grade igneous and metamorphic rocks (Figure 1). The geology of the study area is predominantly migmatite-gneiss complex and metasediments consisting of schists and quartzites, trending approximately NNW-SSE. These rocks either outcrop or are overlain by a mantle of the decomposed kaolinised weathered zone with a thick lateritic crust in some places. There are few outcrops of these rocks in the study area. 


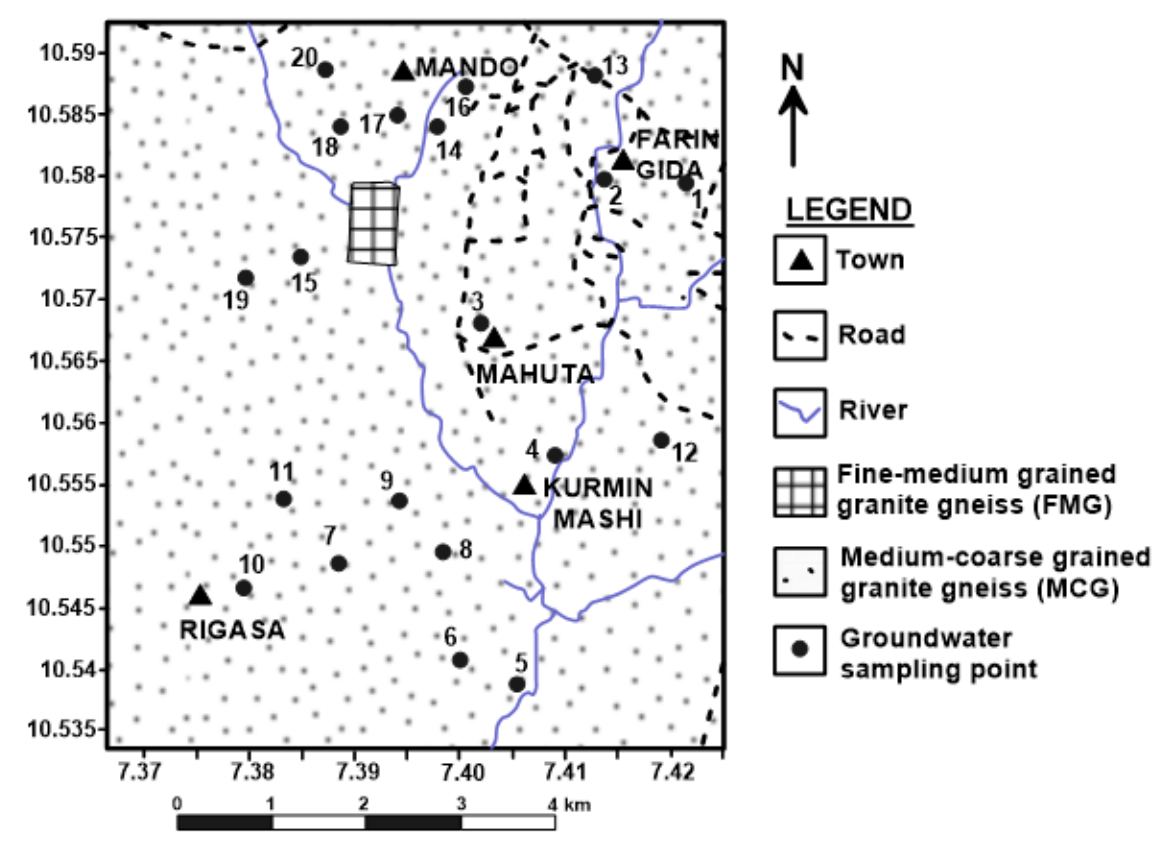

Figure 2. Geological Map of Mando and Rigasa Areas [21]

\subsection{Materials and Methods}

The hand-dug wells within the study area were mapped and their locations determined using the etrex Garmin Global Positioning System (GPS). Groundwater samples for water quality analysis were collected from 20 hand-dug wells within the study area. All the groundwater samples were collected in properly washed plastic bottles, which were first rinsed with some quantity of the groundwater samples before collection. Each of the groundwater sample bottles were properly labelled using paper tape and marker. The electrical conductivity (EC), pH, temperature and total dissolved solids (TDS) of the groundwater were measured in situ with portable WAGTECH electrical conductivity/TDS metre. The cations; $\mathrm{Ca}^{2+}, \mathrm{Mg}^{2+}, \mathrm{Na}^{+}, \mathrm{K}^{+}$and Fe${ }^{2+}$ were analysed using atomic absorption spectrometer (AAS) method at the laboratory of Kaduna Environmental Protection Agency (KEPA). At the laboratory of National Water Resources Institute, Kaduna, analysis for the determination of anionic concentrations of bicarbonate $\left(\mathrm{HCO}_{3}{ }^{-}\right)$, chloride $\left(\mathrm{Cl}^{-}\right)$, sulphate $\left(\mathrm{SO}_{4}{ }^{2-}\right)$ and nitrate $\left(\mathrm{NO}_{3}^{-}\right)$as well as microbiological analysis for the determination and measurement of faecal coliforms in the groundwater samples was carried out. Bicarbonate $\left(\mathrm{HCO}_{3}^{-}\right)$analysis was carried out using acid titration method; chloride ( $\mathrm{Cl}-$ ) concentration was measured by complexometric $\mathrm{AgNO}_{3}$ titration method; sulphate concentration was determined by $\mathrm{BaCl}_{3}$ turbidity method using a spectrophotometer. Nitrate $\left(\mathrm{NO}_{3}{ }^{-}\right)$was measured using $\mathrm{Hach}$ spectrophotometer/cadmium reduction. Faecal Coliforms were measured by membrane filtration technique using WAGTECH kit.

The results obtained from the analysed physical, chemical and microbiological parameters were compared with standard guideline values recommended by Nigerian Standard for Drinking Water Quality (NSDWQ and the World Health Organization (WHO) [] [22, 23]. The degree of compliance of the results with the guidelines was used to assess the groundwater quality. The results of the chemical analysis were plotted on the Piper trilinear diagram. The groundwater was classified on the basis of the region where the data plots on the Piper trilinear diagram. The chemical data were also plotted on the Gibbs diagram. The groundwater quality-controlling mechanism was determined based on the region where the data plots on the Gibbs diagram. Results of physico-chemical analysis were used to calculate the water quality index (WQI) for the groundwater samples using the weighted arithmetic water quality index method [24]. To calculate the WQI, weight was assigned to each of the physico-chemical parameters according to their relative importance in the overall quality of water for drinking purpose [11,25]. The assigned weights ranged from 1 to 5 . The maximum weight of 5 was assigned to nitrate and TDS; 4 for $\mathrm{pH}, \mathrm{EC}, \mathrm{SO}_{4}^{2-} ; 3$ for $\mathrm{HCO}_{3} ; \mathrm{Cl} ; 2$ for $\mathrm{Ca}^{2+}, \mathrm{Na}^{+}, \mathrm{K}^{+}$; and 1 for $\mathrm{Mg}^{2+}$. The relative weight for the $i$ th water quality was computed using Equation 1 [25], while the quality rating $\left(q_{i}\right)$ scale for the $i$ th water quality parameter was computed using Equation 2.

$W_{i}=\frac{w_{i}}{\sum_{i=1}^{n} w_{i}}$

Where,

$W_{i}=$ relative weight of the $i$ th parameter $w_{i}=$ assigned weight of the $i$ th parameter $n=$ number of parameters.

$q_{i}=\frac{c_{i}}{s_{i}} \times 100$

where

$q_{i}=$ quality rating of the $i$ th parameter

$c_{i}=$ concentration of the $i$ th parameter in milligrams per litre

$s_{i}=$ Standard permissible value of the $i$ th parameter in milligrams per litre [23].

Equation 2 ensures that $q_{i}=0$ when no pollutant is present in the water, while $q_{i}=100$ if the concentration of the parameter is equal to the permissible limit for drinking water. Therefore, $q_{i}$ will increase with increase in the concentration of the pollutant. However, the quality rating for $\mathrm{pH}$ requires a different approach. The permissible range of $\mathrm{pH}$ for drinking water is 6.5 to 8.5 , hence the quality rating for $\mathrm{pH}$ is expressed as

$q_{i} p H=\frac{\left(C_{i}-7.5\right)}{7.5} \times 100$ 
Ignoring the algebraic sign in the numerical difference between $\mathrm{c}_{i}$ and 7.5, Equation 3 ensures that $q_{i} p H=0$ for $\mathrm{pH}=7.5$.

For computing the final value of WQI, the sub-index $(S I)$ corresponding to the $i$ th parameter was determined using Equation 3 . The sum of $S I$ values of all the parameters gave the WQI for each of the groundwater samples (Equation 4).

$S I_{i}=W_{i} \times q_{i}$

$W Q I=\sum S I_{i}$

where

$S I_{i}=$ sub-index of $i$ th parameter

$W_{i}=$ relative weight

$\mathrm{q}_{\mathrm{i}}=$ rating based on concentration of ith parameter

$\mathrm{n}$ is the number of parameters.

\subsection{Results and Discussion}

The data obtained from the analysis of the twenty (20) groundwater samples are presented in Table 1 . The pH of the groundwater samples ranged between 5.6 and 7.2 with a mean of 6.6. The temperature values ranged between $26.8{ }^{\circ} \mathrm{C}$ and $28.7^{\circ} \mathrm{C}$ with a mean temperature of $27.8^{\circ} \mathrm{C}$. The $\mathrm{EC}$ ranged between $14.91 \mu \mathrm{S} / \mathrm{cm}$ and $895.00 \mu \mathrm{S} / \mathrm{cm}$ with a mean EC of $191.14 \mu \mathrm{S} / \mathrm{cm}$. The TDS in the groundwater within the study area ranged between $7.37 \mathrm{mg} / \mathrm{L}$ and 447.00 $\mathrm{mg} / \mathrm{L}$ with a mean of $95.22 \mathrm{mg} / \mathrm{L}$. The results obtained from the laboratory chemical analyses of the groundwater samples revealed that the $\mathrm{Ca}^{2+}, \mathrm{Mg}^{2+}, \mathrm{Na}^{+}$, $\mathrm{K}^{+}$and $\mathrm{Fe}^{2+}$ concentrations ranged between $0.02 \mathrm{mg} / \mathrm{L}$ and $44.67 \mathrm{mg} / \mathrm{L}, 0.05 \mathrm{mg} / \mathrm{L}$ and $21.82 \mathrm{mg} / \mathrm{L}, 1.23 \mathrm{mg} / \mathrm{L}$ and $68.40 \mathrm{mg} / \mathrm{L}, 1.50 \mathrm{mg} / \mathrm{L}$ and 31.80 $\mathrm{mg} / \mathrm{L}$, and $0.12 \mathrm{mg} / \mathrm{L}$ and $3.12 \mathrm{mg} / \mathrm{L}$, respectively, while their mean concentrations are $8.47 \mathrm{mg} / \mathrm{L}, 5.92 \mathrm{mg} / \mathrm{L}, 12.65 \mathrm{mg} / \mathrm{L}, 11.11 \mathrm{mg} / \mathrm{L}$ and $1.28 \mathrm{mg} / \mathrm{L}$, respectively. The HCO3-, Cl-, NO3- and SO42- concentrations ranged between $6.00 \mathrm{mg} / \mathrm{L}$ and $90.00 \mathrm{mg} / \mathrm{L}, 3.75 \mathrm{mg} / \mathrm{L}$ and $100.19 \mathrm{mg} / \mathrm{L}, 1.06 \mathrm{mg} / \mathrm{L}$ and $136.00 \mathrm{mg} / \mathrm{L}$, and $0.00 \mathrm{mg} / \mathrm{L}$ and $34.00 \mathrm{mg} / \mathrm{L}$, respectively, while their mean concentrations are $24.15 \mathrm{mg} / \mathrm{L}, 25.89 \mathrm{mg} / \mathrm{L}, 31.01 \mathrm{mg} / \mathrm{L} \mathrm{and} \mathrm{7.25} \mathrm{mg/L,}$ respectively. The chemical data were converted to meq/L to enable quality assurance checks and interpretation of the data using standard charts and tables. The quality assurance of the analysis involved the determination of Cation-Anion Balance (CAB) using Equation 6.

$C A B=\frac{\sum \text { Cations }-\sum \text { Anions }}{\sum \text { Cations }+\sum \text { Anions }} \times 100$

$\mathrm{CAB}$ of less than $5 \%$ indicates that the analysis is within acceptable limits [26]. The CAB obtained for all the groundwater samples were below $5 \%$ except for groundwater samples 11,15 and 17 (Table 2).

\subsection{Groundwater Potability}

The $\mathrm{pH}$ of the groundwater samples ranged between 5.6 and 7.2 with a mean of 6.6. The EC ranged between $14.91 \mu \mathrm{S} / \mathrm{cm}$ and $895.00 \mu \mathrm{S} / \mathrm{cm}$ with a mean $\mathrm{EC}$ of $191.14 \mu \mathrm{S} / \mathrm{cm}$. The TDS in the groundwater within the study area ranged between $7.37 \mathrm{mg} / \mathrm{L}$ and $447.00 \mathrm{mg} / \mathrm{L}$ with a mean of $95.22 \mathrm{mg} / \mathrm{L}$. The pH values of the groundwater in the study area indicate that most of the groundwater fall within the permissible limits of $6.5-8.5$ stipulated by the NSDWQ [22] and WHO [23], except for Samples 6, 14, 16 and 17 with values of 6.4, 6.3, 5.6 and 6.4, respectively. The pH scale has values ranging from zero (0) to fourteen (14), with seven (7) as neutral. Substances with pH less than 7 are acidic while those greater than 7 are alkaline. Four (4) out of the twenty (20) groundwater samples (representing $20 \%$ of the groundwater samples) have pH lower than the minimum permissible limit of 6.5 recommended by NSDWQ [22] and WHO [23]. The groundwater samples with pH less than 6.5 are slightly acidic and not suitable for drinking purpose based on the NSDWQ [22] and WHO [23] guidelines. The regular consumption of acidic water causes derangement of the acid-base balance of the body leading to metabolic acidosis [27]. The range of groundwater temperature of $26.8 \mathrm{oC}$ and $28.7 \mathrm{oC}$ obtained within the study area indicates very little variation in the water temperature. There is no specific recommendation on temperature of potable water. However, high or variable temperature affects aquatic life. The dissolution of substances in water gives rise to ions that can conduct electric current. Therefore, EC is a valuable indicator of the amount of substance dissolved in water. The EC obtained for the groundwater samples ranged between $14.91 \mu \mathrm{S} / \mathrm{cm}$ and $895.00 \mu \mathrm{S} / \mathrm{cm}$ with a mean EC of $191.14 \mu \mathrm{S} / \mathrm{cm}$, while TDS ranged between 7.37 $\mathrm{mg} / \mathrm{L}$ and $447.00 \mathrm{mg} / \mathrm{L}$ with a mean TDS of $95.22 \mathrm{mg} / \mathrm{L}$. The EC and TDS stipulated for potable water indicate a maximum permissible levels of $1000 \mu \mathrm{S} / \mathrm{cm}$ and $500 \mathrm{mg} / \mathrm{L}$, respectively $[22,23]$. The groundwater samples all fall within the permissible limits hence, are suitable for drinking purpose. The very low EC and TDS values obtained for some of the groundwater samples such as Samples 16 and 19 suggest low dissolved ion concentration in the groundwater resulting from poor rock-water interaction in the recharge and transport of the groundwater. The poor rock-water interaction could be as a result of the highly indissoluble nature of the rock or the short residence time of the groundwater within the rock material.

The comparison of the results of physico-chemical analysis with the NSDWQ [22] and WHO [23] guidelines revealed that the ionic concentrations of most of the groundwater samples fall within the permissible limits except in few cases for $\mathrm{pH}, \mathrm{Mg}^{2+}, \mathrm{NO}_{3}{ }^{-}, \mathrm{K}^{+}$and $\mathrm{Fe}^{2+}$ with percentage compliance of 80, 90, 75, 70 and 40, respectively. This indicates that the groundwater samples with ionic concentration above the maximum permissible limits are not potable. Excess magnesium, nitrate and potassium in the human body can alter the rate of heartbeat, lower blood pressure, lead to comma and even death. Excess iron in drinking water causes heart and liver diseases. 
Table 1. Physico-chemical Results

\begin{tabular}{|c|c|c|c|c|c|c|c|c|c|c|c|c|c|c|c|c|c|}
\hline Sample Code & Location & $\begin{array}{l}\text { Lat. } \\
\text { (N) }\end{array}$ & $\begin{array}{l}\text { Long. } \\
\text { (E) }\end{array}$ & pH & $\begin{array}{c}\text { EC } \\
(\mu \mathrm{S} / \mathrm{cm})\end{array}$ & $\begin{array}{c}\text { TDS } \\
(\mathrm{mg} / \mathrm{L})\end{array}$ & $\begin{array}{l}\text { Temp } \\
\left({ }^{\circ} \mathrm{C}\right)\end{array}$ & $\begin{array}{c}\mathrm{Na} \\
\mathrm{mg} / \mathrm{L}\end{array}$ & $\begin{array}{c}\mathrm{K} \\
\mathrm{mg} / \mathrm{L}\end{array}$ & $\begin{array}{c}\mathrm{Ca} \\
\mathrm{mg} / \mathrm{L}\end{array}$ & $\begin{array}{c}\mathrm{Mg} \\
\mathrm{mg} / \mathrm{L}\end{array}$ & $\begin{array}{c}\mathrm{Fe} \\
\mathrm{mg} / \mathrm{L}\end{array}$ & $\mathrm{Cl} \mathrm{mg} / \mathrm{L}$ & $\begin{array}{c}\mathrm{NO}_{3} \\
\mathrm{mg} / \mathrm{L}\end{array}$ & $\begin{array}{l}\mathrm{HCO}_{3} \\
\mathrm{mg} / \mathrm{L}\end{array}$ & $\begin{array}{c}\mathrm{SO}_{4} \\
\mathrm{mg} / \mathrm{L}\end{array}$ & $\begin{array}{c}\text { Faecal } \\
\text { coliform } \\
\text { (cfu/100ml) }\end{array}$ \\
\hline 1 & Faringida & 10.5797 & 7.4154 & 6.6 & 243.00 & 120.00 & 27.8 & 15.80 & 15.40 & 10.44 & 6.13 & 1.57 & 34.74 & 56.00 & 13.00 & 2.00 & TNTC \\
\hline 2 & Mando & 10.5814 & 7.4081 & 6.5 & 438.00 & 218.00 & 27.6 & 18.20 & 28.34 & 24.12 & 20.18 & 1.71 & 68.73 & 110.00 & 31.00 & 7.00 & TNTC \\
\hline 3 & Mahuta & 10.5682 & 7.402 & 6.7 & 130.80 & 65.40 & 27.7 & 10.00 & 4.80 & 1.46 & 8.70 & 0.32 & 13.25 & 20.00 & 28.00 & 7.00 & TNTC \\
\hline 4 & Mahuta & 10.5578 & 7.409 & 6.7 & 105.20 & 52.30 & 27.8 & 5.70 & 2.40 & 1.60 & 5.40 & 0.19 & 3.75 & 6.00 & 34.00 & 6.00 & 100 \\
\hline 5 & H/Danmani & 10.5404 & 7.4046 & 6.8 & 510.00 & 254.00 & 27.7 & 68.40 & 27.44 & 9.10 & 10.17 & 1.87 & 74.23 & 80.00 & 81.00 & 12.00 & TNTC \\
\hline 6 & Rigasa & 10.5421 & 7.4001 & 6.4 & 895.00 & 447.00 & 27.5 & 26.16 & 29.14 & 44.67 & 21.82 & 3.10 & 100.19 & 136.00 & 41.00 & 26.00 & TNTC \\
\hline 7 & Rigasa & 10.5502 & 7.3883 & 6.9 & 29.00 & 14.00 & 27.4 & 4.80 & 4.70 & 0.02 & 0.05 & 0.12 & 3.75 & 3.60 & 11.00 & 0.00 & TNTC \\
\hline 8 & Rigasa & 10.5514 & 7.3992 & 6.9 & 40.50 & 20.30 & 27.5 & 4.23 & 4.74 & 1.16 & 2.60 & 0.17 & 5.75 & 3.00 & 16.00 & 4.00 & 30 \\
\hline 9 & Rigasa & 10.5545 & 7.3944 & 7.1 & 82.70 & 41.40 & 27.4 & 6.50 & 7.23 & 3.97 & 3.46 & 0.19 & 6.75 & 1.40 & 40.00 & 5.00 & TNTC \\
\hline 11 & Rigasa & 10.5543 & 7.3824 & 6.9 & 16.11 & 7.89 & 27.1 & 2.10 & 1.74 & 3.80 & 0.57 & 1.26 & 5.25 & 1.52 & 7.00 & 4.00 & TNTC \\
\hline 12 & K/Mashi & 10.5582 & 7.416 & 6.6 & 358.00 & 179.00 & 26.8 & 23.46 & 25.50 & 22.17 & 8.17 & 1.84 & 38.24 & 12.00 & 90.00 & 34.00 & 1 \\
\hline 13 & Mando & 10.5884 & 7.4041 & 6.5 & 49.20 & 23.70 & 28.4 & 5.62 & 2.50 & 1.14 & 1.80 & 1.44 & 8.75 & 2.00 & 10.00 & 4.00 & TNTC \\
\hline 14 & Mando & 10.5827 & 7.3964 & 6.3 & 115.20 & 57.90 & 28.6 & 13.89 & 14.26 & 3.38 & 1.76 & 1.77 & 21.74 & 24.00 & 13.00 & 4.00 & TNTC \\
\hline 15 & Mashi Gwari & 10.5741 & 7.3866 & 6.8 & 21.50 & 10.50 & 28.6 & 1.60 & 3.18 & 4.54 & 0.21 & 1.31 & 6.75 & 4.20 & 8.00 & 0.00 & 0 \\
\hline 16 & Idi Musa & 10.5873 & 7.3989 & 5.6 & 590.00 & 294.00 & 28.7 & 28.87 & 31.8 & 24.90 & 16.40 & 3.12 & 94.72 & 132.00 & 6.00 & 2.00 & TNTC \\
\hline 17 & Rugan Bello & 10.583 & 7.3937 & 6.4 & 75.20 & 37.40 & 28.5 & 3.14 & 6.47 & 4.70 & 2.21 & 1.81 & 10.25 & 8.00 & 8.00 & 7.00 & TNTC \\
\hline 18 & Lema & 10.5822 & 7.3898 & 6.6 & 49.70 & 24.80 & 28.1 & 6.15 & 4.00 & 1.50 & 2.80 & 1.18 & 6.75 & 16.00 & 10.00 & 3.00 & 200 \\
\hline 19 & Mashi Gwari & 10.5721 & 7.3809 & 6.7 & 14.91 & 7.37 & 28.1 & 4.14 & 3.87 & 1.27 & 1.95 & 1.01 & 6.25 & 1.18 & 7.00 & 9.00 & 200 \\
\hline 20 & Lema & 10.5882 & 7.3871 & 7.2 & 26.20 & 13.00 & 27.9 & 1.23 & 1.50 & 2.84 & 1.52 & 1.31 & 4.25 & 1.06 & 13 & 1 & TNTC \\
\hline
\end{tabular}


Table 2. Physico-chemical Results (meq/L)

\begin{tabular}{|c|c|c|c|c|c|c|c|c|c|c|c|c|c|c|c|c|c|c|}
\hline Sample Code & $\mathrm{Na}$ & $\mathbf{K}$ & $\mathrm{Ca}$ & Mg & Fe & Cl & $\mathrm{NO}_{3}$ & $\mathrm{HCO}_{3}$ & $\mathrm{SO}_{4}$ & $\Sigma($ Cation $)$ & $\Sigma($ Anion) & $\mathrm{CAB}$ & SAR & RSC & PI (\%) & $\mathrm{Na} / \mathrm{Cl}$ & $(\mathrm{Na}-\mathrm{Cl}) / \mathrm{SO}_{4}$ & $\begin{array}{c}\text { (Cl- } \\
\mathrm{Na}) / \mathrm{Mg}\end{array}$ \\
\hline 1 & 0.69 & 0.39 & 0.52 & 0.50 & 0.06 & 0.98 & 0.93 & 0.21 & 0.04 & 2.15 & 2.14 & 0.53 & 0.96 & -0.81 & 67.25 & 0.70 & -7.00 & 0.58 \\
\hline 2 & 0.79 & 0.72 & 1.20 & 1.66 & 006 & 1.94 & 1.77 & 0.51 & 0.15 & 4.44 & 4.37 & 0.86 & 0.66 & -2.36 & 41.14 & 0.41 & -7.86 & 0.69 \\
\hline 3 & 0.44 & 0.12 & 0.08 & 0.72 & 0.01 & 0.38 & 0.32 & 0.46 & 0.15 & 1.36 & 1.30 & 2.14 & 0.69 & -0.33 & 90.75 & 1.16 & 0.41 & -0.08 \\
\hline 4 & 0.25 & 0.06 & 0.08 & 0.44 & 0.01 & 0.11 & 0.10 & 0.56 & 0.13 & 0.84 & 0.89 & -2.63 & 0.48 & 0.03 & 128.79 & 2.31 & 1.13 & -0.32 \\
\hline 6 & 1.14 & 0.74 & 2.23 & 1.79 & 0.11 & 2.83 & 2.19 & 0.67 & 0.54 & 6.02 & 6.23 & -1.74 & 0.80 & -3.35 & 37.94 & 0.40 & -3.12 & 0.94 \\
\hline 7 & 0.21 & 0.12 & 0.00 & 0.01 & 0.00 & 0.11 & 0.06 & 0.18 & 0.00 & 0.34 & 0.35 & -0.54 & 3.07 & 0.17 & 290.52 & 1.95 & 0.00 & -12.35 \\
\hline 8 & 0.18 & 0.12 & 0.06 & 0.21 & 0.01 & 0.16 & 0.05 & 0.26 & 0.08 & 0.58 & 0.56 & 2.31 & 0.49 & -0.01 & 152.19 & 1.12 & 0.23 & -0.09 \\
\hline 9 & 0.28 & 0.18 & 0.20 & 0.29 & 0.01 & 0.19 & 0.02 & 0.66 & 0.10 & 0.96 & 0.97 & -0.64 & 0.57 & 0.17 & 141.81 & 1.47 & 0.87 & -0.32 \\
\hline 10 & 0.14 & 0.08 & 0.13 & 0.21 & 0.01 & 0.11 & 0.04 & 0.26 & 0.17 & 0.57 & 0.57 & -0.17 & 0.33 & -0.08 & 135.19 & 1.26 & 0.17 & -0.13 \\
\hline 12 & 1.02 & 0.65 & 1.10 & 0.68 & 0.06 & 1.08 & 0.19 & 1.48 & 0.71 & 3.52 & 3.45 & 0.90 & 1.08 & -0.30 & 79.89 & 0.95 & -0.08 & 0.08 \\
\hline 13 & 0.24 & 0.06 & 0.06 & 0.15 & 0.05 & 0.25 & 0.03 & 0.16 & 0.08 & 0.56 & 0.53 & 3.04 & 0.77 & -0.04 & 145.19 & 0.98 & -0.06 & 0.03 \\
\hline 14 & 0.61 & 0.37 & 0.17 & 0.15 & 0.06 & 0.61 & 0.39 & 0.21 & 0.08 & 1.35 & 1.30 & 2.16 & 1.52 & -0.11 & 115.59 & 0.98 & -0.09 & 0.05 \\
\hline 15 & 0.07 & 0.08 & 0.23 & 0.02 & 0.05 & 0.19 & 0.07 & 0.13 & 0.00 & 0.44 & 0.39 & 5.83 & 0.20 & -0.11 & 138.98 & 0.36 & 0.00 & 7.43 \\
\hline 16 & 1.26 & 0.81 & 1.24 & 1.35 & 0.11 & 2.67 & 2.13 & 0.10 & 0.04 & 4.77 & 4.94 & -1.71 & 1.10 & -2.49 & 40.81 & 0.47 & -33.96 & 1.05 \\
\hline 17 & 0.14 & 0.17 & 0.24 & 0.18 & 0.06 & 0.29 & 0.13 & 0.13 & 0.15 & 0.78 & 0.70 & 5.73 & 0.30 & -0.28 & 90.28 & 0.46 & -1.07 & 0.86 \\
\hline 18 & 0.27 & 0.10 & 0.08 & 0.23 & 0.04 & 0.19 & 0.26 & 0.16 & 0.06 & 0.72 & 0.68 & 3.15 & 0.69 & -0.14 & 117.32 & 1.41 & 1.25 & -0.34 \\
\hline 19 & 0.18 & 0.10 & 0.07 & 0.17 & 0.04 & 0.18 & 0.02 & 0.12 & 0.19 & 0.54 & 0.50 & 4.27 & 0.53 & -0.12 & 126.79 & 1.00 & 0.00 & 0.00 \\
\hline 20 & 0.05 & 0.04 & 0.14 & 0.13 & 0.05 & 0.12 & 0.02 & 0.21 & 0.02 & 0.40 & 0.37 & 3.63 & 0.14 & -0.05 & 162.92 & 0.43 & -3.32 & 0.56 \\
\hline
\end{tabular}




\subsection{Water Quality Index}

WQI using the physico-chemical parameters were determined for the analysed groundwater samples. WQI calculation for Sample 20 is shown in Table 3. WQI for all other groundwater samples were similarly calculated and the results presented in Table 4. The WQI values obtained range between 2.17 and 72.52. Based on WQI classification (Table 5), fifteen (15) groundwater samples (representing $75 \%$ ) have WQI less than 25 which indicates excellent water quality. Two (2) groundwater samples (representing $10 \%$ ) have WQI between 25 and 50 which indicates good water quality, while three (3) groundwater samples (representing $15 \%$ ) have WQI between 50 and 75 which indicates poor water quality. Groundwater quality map based on the WQI values for the various groundwater samples shows that most part of the study area has excellent groundwater quality, while a small region in the northeastern and southeastern parts of the study area has good to poor groundwater quality (Fig. 3).

\subsection{Bacteriological Assessment}

The faecal coliform bacteria count for this study as shown in Table 1 ranged from $0 \mathrm{CFU} / 100 \mathrm{ml}$ to too numerous to count (TNTC). The NSDWQ [22] and WHO [23] guidelines for drinking water requires that the concentration of faecal coliform should be $0 \mathrm{CFU} / 100 \mathrm{ml}$. Only two (2) groundwater samples (representing $10 \%$ ), which are Samples 10 and 15 comply with the NSDWQ [22] and WHO [23] guidelines hence, are suitable for drinking based on the faecal coliform count. All the other eighteen (18) groundwater samples (representing $90 \%$ ) have faecal coliform count ranging from $1 \mathrm{CFU} / 100 \mathrm{ml}$ to TNTC. Faecal coliform is an indication of contamination by human and animal faeces. The non-compliance of majority of the analysed groundwater samples indicates insanitary conditions around the hand-dug wells.

Table 3. Water Quality Index Calculation for Groundwater Sample 20

\begin{tabular}{|c|c|c|c|c|c|c|}
\hline Parameter & $\begin{array}{c}\text { Weight } \\
\left(w_{i}\right)\end{array}$ & $\begin{array}{c}\text { Relative weight } \\
\mathbf{W}_{i}=\mathbf{w}_{\mathrm{i}} / \Sigma w_{i}\end{array}$ & $\begin{array}{c}\text { WHO standard } \\
\left(\mathrm{S}_{i}\right)\end{array}$ & $\begin{array}{c}\text { Concentration }\left(C_{i}\right) \\
(\mathrm{mg} / \mathrm{L})\end{array}$ & $\begin{array}{c}q i= \\
\left(C_{i} / S_{i}\right) \times 100\end{array}$ & $\mathbf{S I}_{i}=\mathbf{W}_{i}^{*} \mathbf{q}_{i}$ \\
\hline $\mathrm{NO}_{3}^{-}$ & 5 & 0.14 & 50 & 1.06 & 2.12 & 0.30 \\
\hline TDS & 5 & 0.14 & 500 & 13.00 & 2.60 & 0.37 \\
\hline $\mathrm{pH}$ & 4 & 0.11 & $6.5-8.5$ & 7.20 & 96.00 & 0.46 \\
\hline $\mathrm{EC}$ & 4 & 0.11 & 1500 & 26.20 & 1.75 & 0.20 \\
\hline $\mathrm{SO}^{2-}$ & 4 & 0.11 & 250 & 1.00 & 0.40 & 0.05 \\
\hline $\mathrm{HCO}_{3}^{-}$ & 3 & 0.09 & 500 & 13.00 & 2.60 & 0.22 \\
\hline $\mathrm{Cl}$ & 3 & 0.09 & 250 & 4.25 & 1.70 & 0.15 \\
\hline $\mathrm{Ca}$ & 2 & 0.06 & 75 & 2.84 & 3.79 & 0.22 \\
\hline $\mathrm{Na}$ & 2 & 0.06 & 200 & 1.23 & 0.62 & 0.04 \\
\hline K & 2 & 0.06 & 12 & 1.50 & 12.50 & 0.09 \\
\hline \multirow[t]{2}{*}{ Mg } & 1 & 0.03 & 50 & 1.52 & 3.04 & 0.09 \\
\hline & $\Sigma w_{i}=35$ & & & & & $\begin{array}{c}\mathrm{WQI}=\Sigma S \mathrm{l}_{i}=2.1 \\
7\end{array}$ \\
\hline
\end{tabular}

Table 4. Water Quality Index of the Analysed Groundwater Samples

\begin{tabular}{|c|c|c|c|c|}
\hline Sample Code & Location & Lat. (N) & Long. (E) & WQI \\
\hline M1 & Faringida & 10.580 & 7.415 & 26.63 \\
\hline M2 & Mando & 10.581 & 7.408 & 50.86 \\
\hline M3 & Mahuta & 10.568 & 7.402 & 12.22 \\
\hline M4 & Mahuta & 10.558 & 7.409 & 6.94 \\
\hline R5 & H/Danmani & 10.540 & 7.405 & 44.35 \\
\hline R6 & Rigasa & 10.542 & 7.400 & 72.52 \\
\hline R7 & Rigasa & 10.550 & 7.388 & 3.29 \\
\hline $\mathrm{R} 8$ & Rigasa & 10.551 & 7.399 & 3.33 \\
\hline $\mathrm{R} 9$ & Rigasa & 10.554 & 7.394 & 8.66 \\
\hline $\mathrm{R} 10$ & Rigasa & 10.547 & 7.379 & 3.98 \\
\hline R11 & Rigasa & 10.554 & 7.382 & 2.66 \\
\hline K12 & K/Mashi & 10.558 & 7.416 & 21.33 \\
\hline M13 & Mando & 10.588 & 7.404 & 4.29 \\
\hline M14 & Mando & 10.583 & 7.396 & 13.94 \\
\hline M15 & Mashi Gwari & 10.574 & 7.387 & 3.69 \\
\hline M16 & Idi Musa & 10.587 & 7.399 & 59.81 \\
\hline M17 & Rugan Bello & 10.583 & 7.394 & 7.37 \\
\hline M18 & Lema & 10.582 & 7.390 & 8.25 \\
\hline M19 & Mashi Gwari & 10.572 & 7.381 & 3.18 \\
\hline M20 & Lema & 10.588 & 7.387 & 2.17 \\
\hline
\end{tabular}

Table 5. Water Quality Classification Based on WQI values [24]

\begin{tabular}{ccc}
\hline Range & Type of water \\
\hline $0-25$ & Excellent \\
& Good \\
$51-75$ & Poor \\
$76-100$ & Very poor \\
& $>100$ & Unsuitable for drinking \\
\hline
\end{tabular}




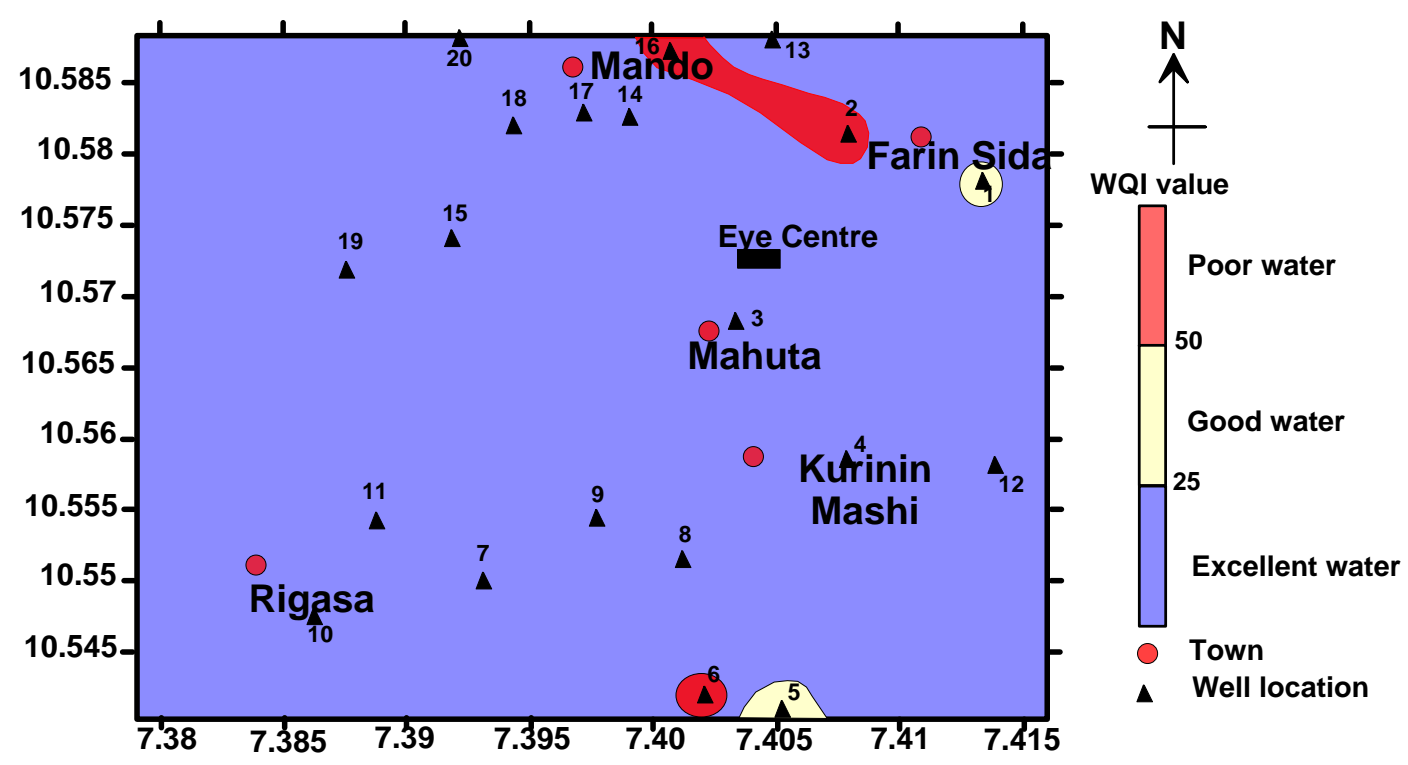

Figure 3. Groundwater Quality Map of Mando and Rigasa areas.

\subsection{Agricultural Use}

Due to the limited supply of rain water in the northern parts of Nigeria, groundwater is used to supplement other water supply systems in agriculture for irrigation purpose and sustenance of animal husbandry. The Sodium Adsorption Ratio (SAR), Residual Sodium Carbonate (RSC) and Permeability Index (PI) of the groundwater samples were determined using Equations 7, 8 and 9, respectively, in order to assess the suitability of the groundwater for agricultural use. The SAR obtained in this study was between 0.14 and 3.70 (Table 6). Comparison of SAR obtained for this study with the SAR of groundwater for agricultural use (Table 2) revealed that all the groundwater samples have SAR less than the maximum permissible limit of 10 and are therefore excellent for agricultural use.

$S A R=\frac{N a^{+}}{\sqrt{\frac{C a^{2+}+M g^{2+}}{2}}}$

$R S C=\left(\mathrm{CO}_{3}^{-2}+\mathrm{HCO}_{3}^{-}\right)-\left(\mathrm{Ca}^{2+}+\mathrm{Mg}^{2+}\right)$

$\mathrm{PI}=\frac{\mathrm{Na}^{+}+\sqrt{\mathrm{HCO}_{3}^{-}}}{\mathrm{CO}_{3}^{-2}+\mathrm{HCO}_{3}^{-}+\mathrm{Na}^{+}} \times 100$

Table 6. Water classification using SAR [28]

\begin{tabular}{|l|l|l|}
\hline SAR & Water Class & SAR \\
\hline$<10$ & Excellent, No problem & $0.14-3.70$ \\
\hline $10-18$ & Good (Medium) Increasing Problem & \\
\hline $18-26$ & Poor (High) Severe Problem & \\
\hline$>26$ & Very High & \\
\hline
\end{tabular}

The RSC values obtained for this study ranged between $-2.49 \mathrm{meq} / \mathrm{L}$ and $0.17 \mathrm{meq} / \mathrm{L}$ (Table 2). For water to be suitable for agricultural purpose the RSC must be $<1.25$ meq/L [29]. Based on the RSC the groundwater samples are suitable for agricultural use. High concentrations of $\mathrm{HCO}_{3}{ }^{-}$correspond to high values of RSC. High RSC indicates an alkaline nature of the water, making the water unsuitable for agricultural purpose. The PI obtained for this study ranged between $40.81 \%$ and 290.52 \% (Table 2). Water, based on PI can be grouped as Class I, Class II or Class III (Table 7). The groundwater samples for this study fall within Class I and Class II, hence the groundwater is suitable for agricultural use (Table 4).

Table 7. Permeability index chart [30]

\begin{tabular}{|l|l|l|l|}
\hline PI (\%) & Class & PI Present Study & Remark \\
\hline$>50$ & Class I & 17 samples & Safe for irrigation \\
\hline $25-50$ & Class II & 3 samples & Marginal Quality \\
\hline$<25$ & Class III & Nil & Unsuitable for irrigation \\
\hline
\end{tabular}

\subsection{Groundwater Origin}

Using the Sulin [31] classification (Table 8), Eleven (11) groundwater samples (55 \%) were of connate origin while the rest nine (9) groundwater samples (45\%) were of meteoric origin (Table 2). Out of the 11 groundwater samples of connate origin, eight (8) belonged to the chloride-magnesium class while the remaining three (3) connate groundwater samples belonged to the chloride-calcium class. All the meteoric groundwater fall under the sulphate-sodium 
class of the Sulin [31] classification. Despite the difference in the origin of the groundwater samples, the Schoeller [32] semi-logarithmic graph showed that based on the concentration of the major ionic constituents, the groundwater samples could be classified as having similar source due to the similarity in the pattern of the curves exhibited by the different groundwater samples (Fig. 4). On the Piper [33] trilinear diagram (Fig. 5), the groundwater samples have varied groundwater facie types. Samples 2 and 6 are of the $\mathrm{CaSO}_{4}$-type, typical of gypsum groundwater and mine drainage. Samples 4,10 and 20 are of the $\mathrm{CaHCO}_{3}$-type, typical of shallow fresh groundwater. Samples 5, 13, 14 and 18 are of the NaCl-types, typical of deep ancient groundwater. Sample 7 is of the $\mathrm{NaHCO}_{3}$-types, typical of deeper groundwater influenced by ion exchange. Samples 1, 16, 17 and 19 are of the CaSO $\mathrm{C}_{4} \mathrm{NaCl}$-type. This type of groundwater is a mixture of the gypsum groundwater and mine drainage, and the deep ancient groundwater. Samples 3,8 and 12 are of the $\mathrm{CaHCO}_{3}-\mathrm{NaCl}_{-}$ type. This type of groundwater is a mixture of the shallow fresh groundwater and the deep ancient groundwater. Sample 9 is of the $\mathrm{CaHCO}_{3}-\mathrm{NaHCO}_{3}$-type. This type water is a mixture of the shallow fresh groundwater and the deeper groundwater influenced by ion exchange. Samples 11 and 15 are of the $\mathrm{CaSO}_{4}$ $\mathrm{CaHCO}_{3}-\mathrm{NaCl}$-type, indicating a mixture of three (3) water types. These water types are the gypsum and mine drainage water, shallow fresh groundwater and the deep ancient groundwater. The groundwater in Mando and Rigasa areas is dominated by Na-Cl-type facies, followed by CaHCO${ }_{3}$-type facies. This suggests that the alkalis $\left(\mathrm{Na}^{+}+\mathrm{K}^{+}\right)$dominate over the alkaline earth ions $\left(\mathrm{Ca}^{2+}+\mathrm{Mg}^{2+}\right)$ and $\mathrm{Cl}^{-}$is the dominant anion. The relatively higher concentration of $\mathrm{Na}^{+}$compared to the low $\mathrm{Ca}^{2+}$ concentration suggests that $\mathrm{Ca}^{2+}$ and $\mathrm{Na}^{+}$ion exchange is an important geochemical process for the $\mathrm{Na}-\mathrm{Cl}$ type of groundwater in the area.

Table 8. Classification of groundwater samples [31]

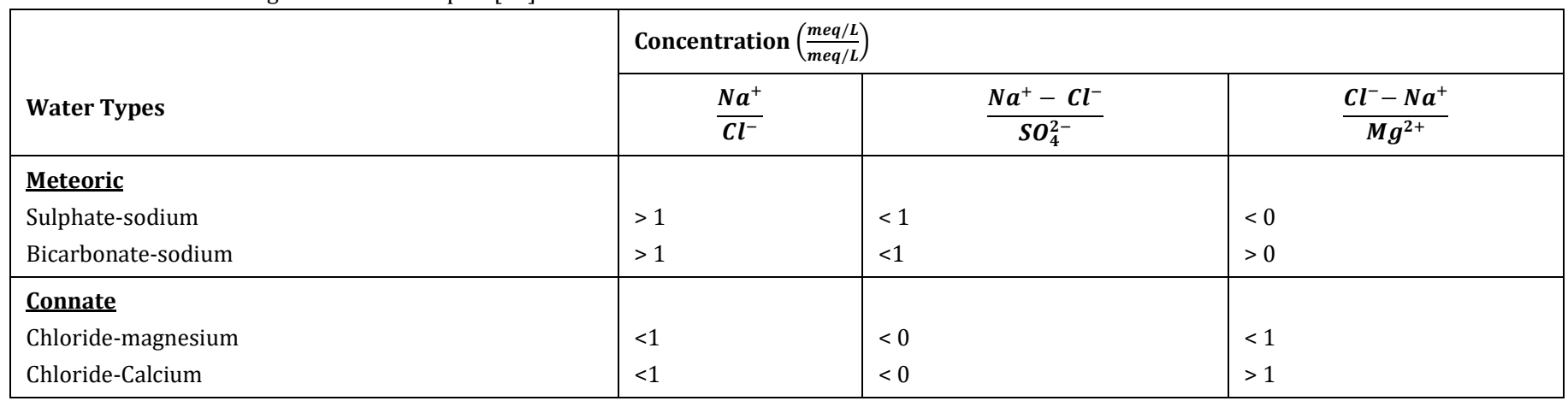

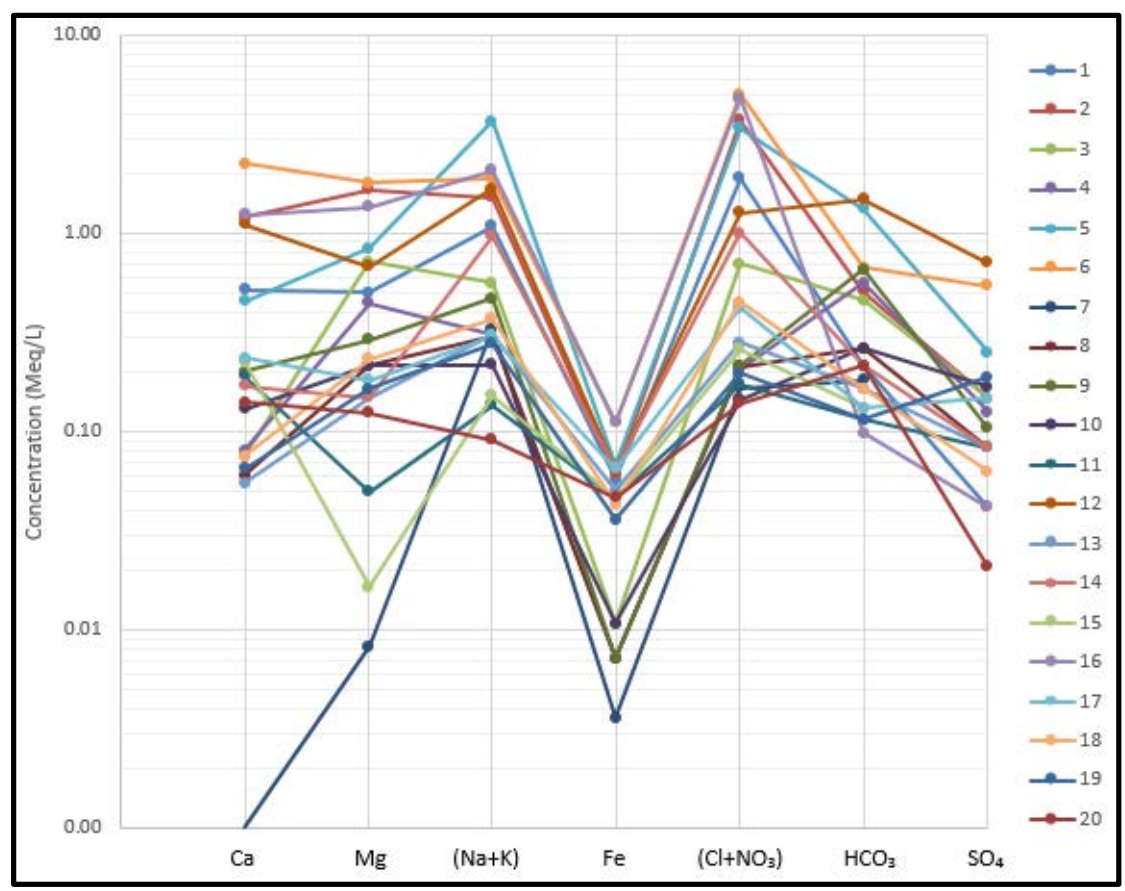

Figure 4. Schoeller Semi Logarithmic Plot of the Groundwater Samples [32] 


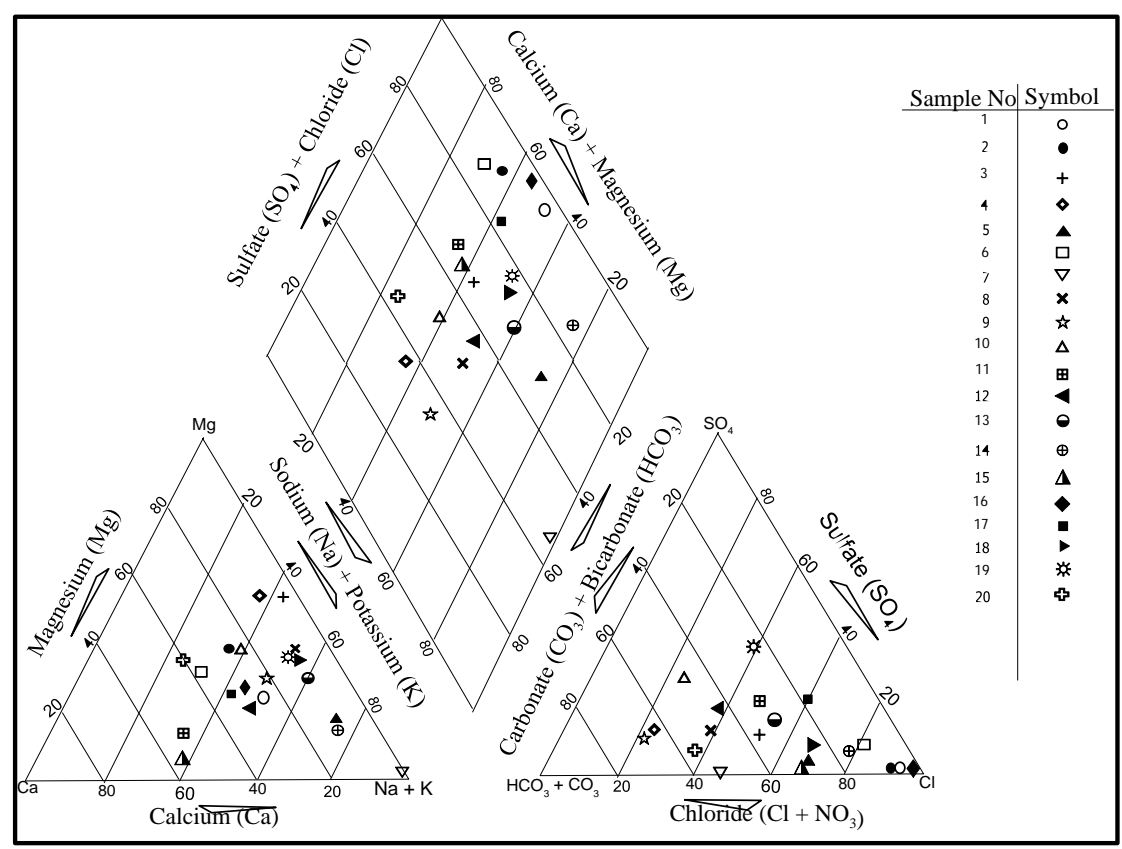

Figure 5. Trilinear plots of the groundwater samples [34]

The Gibbs plot was used to show the relationship between the water composition with respect to aquifer characteristics such as rock-water interaction, rainfall dominance (i.e. chemistry of precipitated water) and evaporation for groundwater chemistry [35]. From the Gibbs plots, most of the samples fall within the two fields (Fig. 6). The first field is the rock-water interaction dominance, which indicates that chemical weathering of rock-forming minerals influences the groundwater chemistry by dissolution of rocks through which the water circulates. The second field is the precipitation dominance, which suggests that evaporation control field increases salinity by increasing the concentrations of $\mathrm{Na}$ and $\mathrm{Cl}$ ions in relation to increase in TDS and probably agricultural inputs. Some of the samples fall outside the plot, which may indicate other processes of anthropogenic activities.

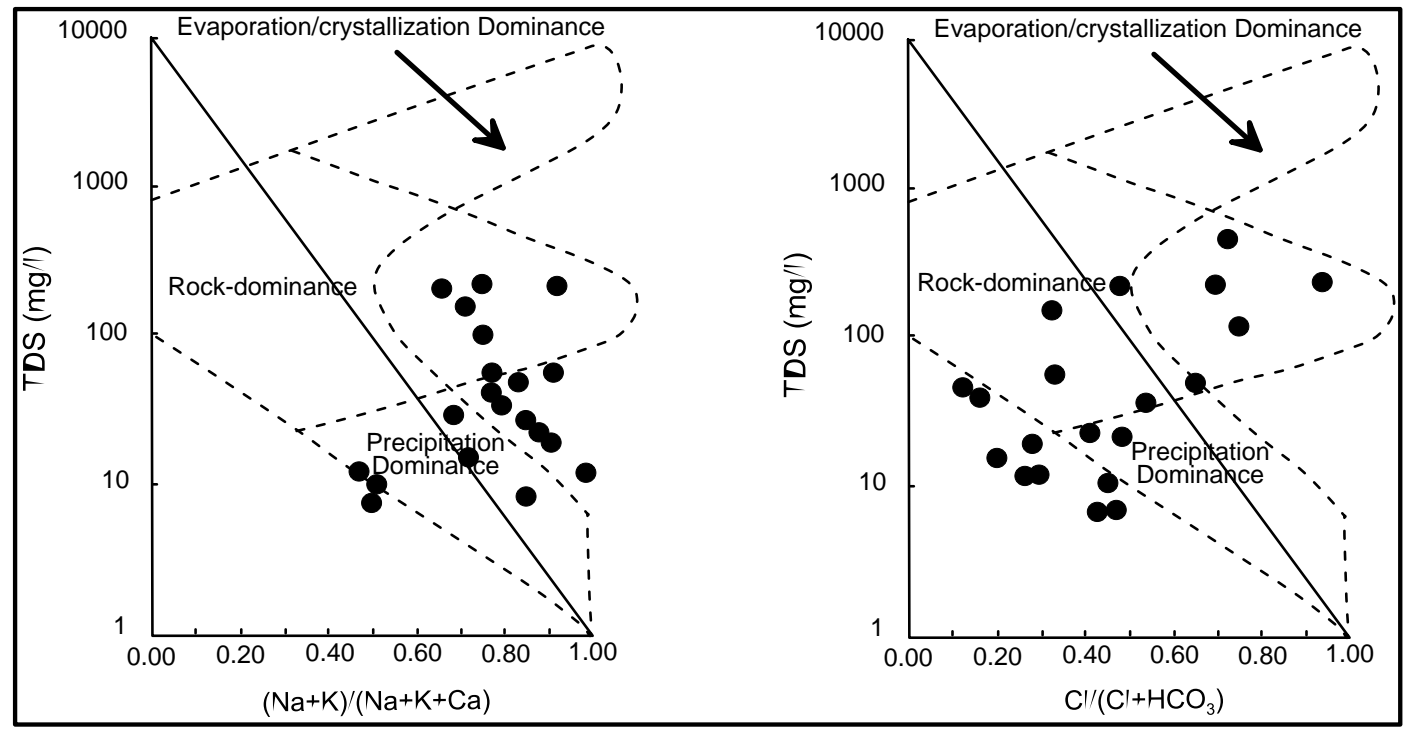

Figure 6. Gibbs diagram for groundwater quality-controlling mechanisms in Mando and Rigasa areas

\subsection{Conclusions}

The quality of groundwater from twenty (20) hand-dug wells around the Mando and Rigasa areas, Northwestern Nigeria was evaluated to determine its hydrochemistry and suitability for drinking and agricultural purposes. Physico-chemical parameters such as pH, EC, TDS, temperature, $\mathrm{Na}^{+}, \mathrm{Ca}^{2+}, \mathrm{K}^{+}, \mathrm{Mg}^{2+}$, $\mathrm{Fe}^{2+}, \mathrm{Cl}, \mathrm{HCO}_{3}-\mathrm{NO}_{3}-\mathrm{SO}_{4}{ }^{2-}$ and faecal coliform count were analysed. The results revealed that the ionic concentrations of most of the groundwater samples fall within the permissible limits and are potable except in few cases for $\mathrm{pH}, \mathrm{Mg}^{2+}, \mathrm{NO}_{3}{ }^{-}, \mathrm{K}^{+}$and $\mathrm{Fe}^{2+}$ with percentage compliance of 80, 90, 75, 70 and 40, respectively. Groundwater quality map based on the WQI showed that most part of the study area has excellent groundwater quality, while a small region in the northeastern and southeastern parts of the study area has good to poor groundwater quality. Most of the groundwater samples are not suitable for drinking based on faecal coliform count. Only two (2) groundwater samples (10\%) comply with the 0 CFU/100 ml guidelines of the NSDWQ [22] and WHO [23], while the rest eighteen (18) groundwater samples (90\%) have faecal coliform bacteria count above the recommended value. This indicates insanitary conditions around most of the hand-dug wells. The groundwater samples are suitable for agricultural purposes based on the SAR, RSC and PI analysed. The $\mathrm{Na}$-Cl-type and $\mathrm{CaHCO}_{3}$-type facies groundwater are the most dominant in the Mando and Rigasa areas, while the $\mathrm{Cl}^{-}$is the dominant anion. The Gibbs plots revealed that the groundwater quality controlling mechanisms are mainly the rock-water interaction and ionic precipitation. 


\subsection{References}

[1] B.S. Terhemba, D.N. Obiora, C.U. Josiah, E.O. Paul, J. Hilary, and J.C. Ibuot, “Aquifer Vulnerability Mapping in Katsina-Ala Area, Central Nigeria Using Integrated Electrical Conductivity (IEC)”, Journal of Environment and Earth Science, Vol. 6, No. 6, Pp. 66 - 75, 2016.

[2] United Nations Water, UN-Water, Water for a Sustainable World, The United Nations World Water Development Report. Paris, France: United Nations Educational, Scientific and Cultural Organisation, 2015.

[3] A. Du Plessis, "Freshwater Challenges of South Africa and its Upper Vaal River", Current State and Outlook. Springer, London, 2017.

[4] African Groundwater Network, AGW-NET, Integration of Groundwater Management into Transboundary Basin Organizations in Africa- a Training Manual by AGW-Net, BGR, IWMI, CapNet, ANBO, and IGRAC, 2015.

[5] National Water Resources Institute- Rural Water Supply and Sanitation Centre, NWRI-RWSSC, Course 3. Drilling Technology. NWRI-RWSSC, Kaduna, 2012.

[6] M. Lyu, Z. Pang, L. Yin, J. Zhang, T. Huang, S. Yang, Z. Li, X. Wang, and T. Gulbostan, “The Control of Groundwater Flow Systems and Geochemical Processes on Groundwater Chemistry: A Case Study in Wushenzhao Basin, NW China", Water, 11, 790, 2019.

[7] B. Agoubi, "Assessing hydrothermal groundwater flow path using Kohonen's SOM, geochemical data, and groundwater temperature cooling trend", Environ Sci. Pollut. Res., 25, Pp. 13597-13610, 2018. https://doi.org/10.1007/s11356-018-1525-1

[8] G. Bartzas, F. Tinivella, L. Medini, D. Zaharaki, and K., Komnitsas, "Assessment of groundwater contamination risk in an agricultural area in north Italy", Information Processing in Agriculture, Vol. 2, No. 2, 2015. https://doi.org/10.1016/j.inpa.2015.06.004

[9] N. Sasakova, G. Gregory, D. Takacova, J. Mojzisova, L. Papajova, J. Venglovsky, T. Szaboova, and S. Kovacova, "Pollution of Surface and Ground Water by Sources Related to Agricultural Activities", Front. Sustain. Food Syst., 2018. https://doi.org/10.3389/fsufs.2018.00042

[10] A. Nigusse, A. Bairu, N. Tadesse, and K. Bheemalingeswara, 2011. Effect of Chemical and Mineralogical Composition of Rocks on the Groundwater Chemistry of Hewanie and its Surrounding Areas, Southern Tigray, Ethiopia. Ethiopian Journal of Environmental Studies and Management. Vol. 4, No. 4, 2011. http://dx.doi.org/10.4314/ejesm.v4i4.3

[11] M.F. Howladar, M.A. Al Numanbakth, and M.O. Faruque, "Application of Water Quality Index (WQI) and Multivariate Statistics to Evaluate the Water Quality Around Maddhapara Granite Mining Industrial Area, Dinajpur, Bangladesh”, Environmental Systems Research, Vol. 6, Pp. 13-22, 2017. https://doi.org/10.1186/s40068-017-0090-9.

[12] B. Maina, and A.C. Eziashi, "Effects of Sewage Disposal on Groundwater Quality in Gombe Metropolis, Gombe State, Nigeria”, Lap Lambert Academic Publishing, Pp. 82, 2017.

[13] U.U. Udiba, I. Bashir, N.S. Akpan, S. Olaoye, U.I. Idio, E.H. Odeke, V. Ugoji, S. Anyajara, and T.D.T. Agboun, "Impact of Mining Activities on Ground Water Quality Status, Dareta Village, Zamfara, Nigeria", Archives of Applied Science Research, Vol. 5, No. 1, Pp. 151-158, 2013.

[14] V. Sunitha, B. Muralidhara Reddy, and M. Ramakrishna Reddy, "Groundwater Contamination from Agro-chemicals in Irrigated Environment: Field Trials", Advances in Applied Sciences Research, Vol. 4, No. 3, Pp. 5-9, 2013.

[15] A.S. Oke, "Regional Aquifer Vulnerability and Pollution Sensitivity Analysis of Drastic Application to Dahomey Basin of Nigeria", Int. J. Environ. Res. Public Health, Vol. 17, Pp. 2609, 2020. doi:10.3390/ijerph17072609.

[16] C.N. Egbinola, and A.C. Amanambu, "Groundwater Contamination in Ibadan, South-West Nigeria”, SpringerPlus, 2014. DOI: 10.1186/2193-1801-3448.

[17] F.J. Ogbozige, D.B. Adie, S.B. Igboro, and A. Giwa, "Evaluation of the Water Quality of River Kaduna, Nigeria Using Water Quality Index", J. Appl. Sci. Environ. Manage., Vol. 21, No. 6, Pp. 1119-1126, 2017. https://dx.doi.org/10.4314/jasem.v21i6.21.

[18] World Health Organisation, 2019. Drinking Water. https://www.who.int/news-room/fact-sheets/detail/drinking-water (Accessed 15 March 2021).

[19] L.M. Maniyunda, B.A. Raji, A.C. Odunze, and W.B. Malgwi, "Forms and Content of Sesquioxides in Soils on Basement Complexes of Northern Guinea Savanna of Nigeria", Journal of Soil Science and Environmental Management, Vol. 6, No. 6, Pp. 148 - 157, 2015. DOI 10.5897/JSSEM13. 0428.

[20] Nigerian Meteorological Agency, NIMET. Rainfall data for Kaduna, Pp. 1981-2015, 2017.

[21] J.A. Alimi, "Vulnerability Mapping of Shallow Aquifers and Groundwater Quality Evaluation in Mando/Rigasa Area (part of Kaduna Sheet 123 SE) Northwestern Nigeria", Unpublished M.Sc. Thesis, Department of Geology, Federal University of Technology Minna, Pp. 68, 2019.

[22] National Standards for Drinking Water Quality (NSDWQ), "Nigerian Standard for Drinking Water Quality", NIS 554:2015, Standards Organisation of Nigeria (SON), 2015.

[23] World Health Organisation (WHO), "Guidelines for Drinking-Water Quality: Fourth Edition Incorporating the First Addendum", Geneva: World Health Organisation, 2017.

[24] V. Calmuc, M. Calmuc, M.C. Topa, M. Timofti, C. Iticescu, and L. Georgescu, "Various Methods for Calculating the Water Quality Index. Annals of "Dunarea de Jos", University of Galati Mathematics, Physics, Theoretical Mechanics Fascicle II, Year X (XLI), Vol. 2 no. 9, 2018. https://doi.org/10.35219/annugal-math-phys-mec.2018.2.09

[25] S.K. Kumar, A. Logeshkumaran, N.S. Magesh, P.S. Godson, and N. Chandrasekar, "Hydro-geochemistry and Application of Water Quality Index (WQI) for Groundwater Quality Assessment, Anna Nagar, part of Chennai City, Tamil Nadu, India”, Applied Water Science, Vol. 5, Pp. 335-343, 2014. https://doi.org/10.1007/s13201-014-0196-4. 
[26] C.W. Fetter, "Applied Hydrogeology", 4th Edition. Waveland Press, 2018.

[27] A.E. Ofoma, D.A. Omologbe, and P. Aigbema, "Physic-chemical Quality of Groundwater in Parts of Port-Harcourt City, Eastern Niger Delta", Water Resource, Vol. 16, Pp. 18-24, 2005.

[28] M.E. Offodile, “Hydrogeology: Ground Water Study and Development in Nigeria”, 3rd Edition. Mecon Geology and Engineering Services Ltd, 2014.

[29] S. Venkateswaran, and S. Vediappan, "Assessment of Groundwater Quality for Irrigation Use and Evaluate the Feasibility Zones through Geospatial Technology in Lower Bhavani Sub Basin, Cauvery River, Tamil Nadu, India", International Journal of Innovative Technology and Exploring Engineering, Vol. 3, No. 2, Pp. 180 - 187, 2013.

[30] M.J. Dhirendra, K. Alok, and A. Namita, "Assessment of the Irrigation Water Quality of River Ganga in Haridwar District, Rasayan", J. Chem. Vol. 2, No. 2, Pp. 285 - 292, 2009.

[31] V.A. Sulin, "Water of Oil Reservoirs in the Systems of Natural Waters: (Vody Neftyanykh Mestorozhdelin V Sisteme Prirodnikh Vod) Moscow", Gostoptekhizdat, 1946.

[32] H. Schoeller, “La classification gèochimique des eaux. I. A. S. H. Publication no 64, Gen”, Assembly of Berkeley, VoL. 4, pp. 16 - 24, 1964.

[33] A.M. Piper, "A Graphic Procedure in the Geochemical Interpretation of Water Analyses", Transactions, American Geophysical Union, 25, Pp. 914 - 923, 1944.

[34] S.N. Davis, and R.J.M. de Wiest, “Hydrogeology”, John Wiley, New York, 1966.

[35] S. Selvakumar, N. Chandrasekar, and G. Kumar, "Hydrogeochemical Characteristics and Groundwater Contamination in the rapid Urban Development Areas of Coimbatore, India", Water Resources and Industry, Vol. 17, Pp. 26-33, 2017. https://doi.org/10.1016/j.wri.2017.02.002. 